\title{
Yamuna KALUARACHCHI \\ Potential advantages in combining smart and green infrastructure over silo approaches for future cities
}

\author{
(C) The Author(s) 2020. This article is published with open access at link.springer.com and journal.hep.com.cn
}

\begin{abstract}
Cities are incorporating smart and green infrastructure components in their urban design policies, adapting existing and new infrastructure systems to integrate technological advances to mitigate extreme weather due to climate change. Research has illustrated that smart green infrastructure (SGI) provides not only climate change resilience but also many health and wellbeing benefits that improve the quality of life of citizens. With the growing demand for smart technology, a series of problems and challenges, including governance, privacy, and security, must be addressed. This paper explores the potential to transition from grey, green, or smart silos to work with nature-based solutions and smart technology to help change cities to achieve considerable environmental and socio-economic benefits. The concepts of grey, green, and smart infrastructure are presented, and the needs, benefits, and applications are investigated. Moreover, the advantages of using integrated smart, green nature-based solutions are discussed. A comprehensive literature review is undertaken with keyword searches, including journal papers, stakeholder and case study reports, and local authority action plans. The methodology adopts multimethod qualitative information review, including literature, case studies, expert interviews, and documentary analysis. Published data and information are analysed to capture the key concepts in implementing SGI systems, such as storm-water control, flood and coastal defense, urban waste management, transportation, recreation, and asset management. The paper investigates the elimination of silo approaches and the alleviation of the destructions caused by extreme weather events using these interdependent SGI systems supported by novel datadriven platforms to provide nature-based solutions to boost the health and wellbeing of the residents.
\end{abstract}

Received June 21, 2019; accepted July 20, 2020

Yamuna KALUARACHCHI ( $ه)$

The School of the Built Environment and Architecture, London South Bank University, London SE1 0AA, UK

E-mail: kaluaray@1sbu.ac.uk
Keywords grey infrastructure, green infrastructure, smart infrastructure, smart and green combined infrastructure, smart cities, future cities

\section{Introduction}

Rapid urbanisation leads to the creation, extension, and transformation of cities at an unprecedented rate. A total of $55 \%$ of the world's population lives in cities, and this percentage is expected to increase to $68 \%$ by 2050 (UN, 2018). Living in modern cities can be challenging and detrimental to health due to pollution and physical and mental stresses. Thus, city dwellers are beginning to prioritise their quality of life and wellbeing. Access and usage of green spaces have been indicated to deliver health benefits, from improved mental wellbeing and levels of physical activity to reduced exposure to pollution and high urban temperatures (Wentworth, 2013). A future livable city should aim to create holistic, integrated, and lowcarbon solutions that deliver social, economic, environmental, wellbeing, and resource security through the development of innovative technological pathways.

Improved resilience allows cities to adapt and transform to face many challenges, including climate change, population increase, inadequate infrastructure, pandemics, or cyber-attacks (Urban Resilience, 2019). With the increased threat of climate change due to extreme weather events, maximising infrastructure resilience is necessary. Infrastructure resilience is defined as the physical coping capacity that ensures rapid restoration of processes and procedures, guaranteeing clear and effective communication to all stakeholders to minimise the impact (Committee on Climate Change, 2017a). City infrastructure is used to provide public services, such as transport, water usage, and waste treatment (Papayanis and Wakeman, 2019), and facilitate the use of public spaces for commerce, civic, and recreational activities. Traditional man-made infrastructure solutions are referred to as gray infrastructure. Green infrastructure is the combination of infrastructure elements 
with natural elements and multifunctional green spaces (UK Green Building Council, 2015). Despite the predictable life span, depreciation, and return on investment of gray infrastructure assets (Alberta Water Portal Society, 2019), increased use of hard surfaces, such as asphalt and concrete, leads to reduced surface water infiltration, which is particularly relevant in the current climate of urbanisation and extreme weather events. Hence, gray infrastructure is perceived as inflexible investments in the integration of green and gray, which is regarded as next-generation infrastructure (The World Bank, 2019). Green solutions were previously neglected due to a lack of robust methods to compare gray and green. However, the development of green-gray-analysis methods (Talberth and Hanson, 2012; Talberth et al., 2013; Browder et al., 2019) has demonstrated the long-term benefits in investment and up-scaling of green infrastructure. Combining these new infrastructure solutions with novel technological systems that are "smart" and supported by data and communications is the way forward for future cities to realize their long-term sustainable goals (ITU, 2014). This paper focuses on the benefits of combining green and smart integrated infrastructure solutions compared with gray, green, or smart silo usages and provides recommendations regarding the implementation of these solutions.

The relationships between gray, green, and smart technologies are evolving. These technologies change with the stakeholder responses to climate change and increased environmental consciousness prompted by the development of innovative technological systems. With the advancement in technology, the concept of "smart", which incorporates sensors, databases, and wireless access to sense, adapt, and provide services for users within the city environment collaboratively, has inspired possible "smart city" solutions for urban challenges. Incorporated within these solutions are "smart networks", a collection of connected devices that allow data transfer and of different kinds of information, such as connectivity, functions, and performance (Quant, 2019). This combination of digital technology and physical urban infrastructure has introduced the concept of "smart infrastructure", where sensing technologies are embedded in infrastructure and the equipment they interact with, allowing for real-time data acquisition and analysis. In such systems, the information is gathered, analyzed, interpreted, and delivered as reliable, robust, and meaningful information to infrastructure providers, who can then make informed decisions regarding the structural health and maintenance of their assets.

The benefits of green infrastructure and smart infrastructure have been well discussed, researched, and documented (Science for Environment Policy, 2012; UK Green Building Council, 2015; Smart Cities World, 2018). Green infrastructure contributes to maintaining a balanced ecosystem and providing environmental, social, and economic benefits (Science for Environment Policy, 2012; Wang and Banzhaf, 2018). Smart infrastructure mainly relies on technology to deliver these benefits. Both systems deliver benefits and increased efficiency. And, green infrastructure has the potential to offer win-win solutions by tackling several problems simultaneously, thus providing many benefits while remaining within a financially viable framework (Science for Environment Policy, 2012). However, many examples of infrastructure projects highlighted as smart and green are mainly or only smart, supported by information and communication technology (ICT) (UCLG, 2017; 2019; Woetzel et al., 2018). These projects mainly focus on the following:

- Mobility and Connectivity - improving how people travel and communicate;

- Health-Healthy Aging - enhancing quality of life, mental health, and wellbeing;

- Skills and Enterprise - managing supply and demand; up-skill local population and talent for innovation; advancement of enterprise levels and sustainable start-up and business growth;

- Information Marketplaces - enabling program of activity and creating conditions for data extraction and/or exchange by multiple partners and stakeholders prioritised around above themes.

The combination of green and nature-based features that help solve urban and environmental challenges with smart technology and IT systems can be defined as smart green infrastructure (SGI). The two concepts currently operate in parallel and largely independently, despite the multitude of long-term benefits that can be achieved with their integration. This paper identifies this opportunity and explores how combining smart and green can provide integrated solutions for complex urban city challenges while improving resilience (Godfrey, 2012).

SGI components can contribute to reducing greenhouse gases, improving transport assets, reducing flooding and urban heat islands, and enhancing the aesthetics of cities and the wellbeing of urban populations (Wray, 2017). With the rapid occurrence of urbanisation, sustainability and the health of future cities will rely on natural green areas supported by smart services. The ability to collect digital real-time data could prove pivotal in identifying areas of improvement in the performance of green infrastructure components, bridging the gap between green and smart (Kaluarachchi, 2019a). These data will help improve the efficiency and usage of water and energy while reducing air pollution and increasing biodiversity. Mapping areas of deficiency and highlighting potential areas of improvement will also help planners, facility and estate managers, and the construction industry to come together to up-scale SGI development.

This paper aims to explore the advantages of transitioning from gray, green, or smart silo solutions to working with nature and technology combined solutions to help transform cities. This transition will provide a multitude of benefits while making cities resilient to climate change and transforming them into healthy places to live. The needs 
and benefits of implementing combined green and smart solutions are also examined. Urban systems that can benefit from the incorporation of SGI components and the challenges that can be encountered due to their interdependent nature in city operations are identified. A comprehensive literature review is undertaken with keyword searches, including journal papers, stakeholder reports, case studies, and action plans. This review mainly encompasses an analysis of the potential to use green infrastructure within smart cities and a systematic review of smart and green city performance measurement systems. The methodology employs a multimethod qualitative information review, which included literature, case studies, expert interviews, and documentary analysis. Case study materials relating to existing smart cities are also examined, including Masdar City in Abu Dhabi, Songdo in South Korea, Eko City in Nigeria, and other European smart city projects. Published data and information are analyzed to capture the key concepts in implementing SGI systems, such as storm-water control, flood and coastal defense, urban waste management, transportation, recreation, and asset management.

The paper presents the advantages and limitations of gray, green, and smart infrastructure and the evolving relationships among them. An analysis of the benefits of integrating green and smart infrastructure is also provided. The utilization of these integrated and co-dependent systems to address future urban city challenges is discussed. The paper also offers insights into the elimination of silo and the mitigation of damage caused by extreme weather events by combining SGI components and systems to provide nature-based solutions to boost the health and wellbeing of residents. Finally, this paper presents a schematic figure that illustrates the relationships between integrated infrastructure systems and drivers that can contribute to achieving future cities.

\section{Grey, green, and smart infrastructure concepts}

Grey infrastructure, which is essential to the functions of cities, refers to constructed assets that provide services, such as transportation, treatment facilities, sewer and storm water systems, or storage basins. The term "gray" refers to the fact that such structures are often made of concrete (NGICP and IGICP, 2018). Grey infrastructure is designed to provide essential urban functions. However, they hinder natural processes, including the natural flow and filtration of surface water, the migration of animals, the food chain, and plant succession (Benedict and McMahon, 2002). Grey or built infrastructure is designed to provide a single specific service, such as drainage or transport (Liquete et al., 2015). By contrast, green infrastructure has been introduced in planning theories and policies (Lennon, 2015) to incorporate broad development ideas considering numerous aspects, such as social, recreational, and ecological implications.

An interconnected network of green spaces, which comprise urban parks, individual gardens, green walls and roofs, urban wetlands, and community and tenement plots, is designed and managed to offer a variety of environmental, social, and economic benefits (Foster et al., 2011). This network is referred to as green infrastructure. Among other ecosystem service benefits, this network also offers opportunities for carbon capture, temperature regulation, flood, wind speed, and storm water runoff reduction, and food production (Brown et al., 2015; Kaluarachchi, 2019a).

The "smart city" agenda seeks to use technology, complex data, and information platforms to help in decision making and promoting efficient operational networks in the city (Albino et al., 2015; Woetzel et al., 2018). Sectors, such as energy grids, drainage systems, smart pricing (parking, transport, energy, and water), and transport and communications, can implement these networks to achieve efficiency and save cost. These sectors are known as smart infrastructure systems. With the integration of green infrastructure to increase city resilience, the resulting integrated systems can handle complex city problems and achieve long-term sustainability (UCLG, 2017; 2019; NGICP and IGICP, 2018; Kaluarachchi, 2019b) (Fig. 1).

\section{The need for smart and green infrastructure implementation}

Cities comprise $2 \%$ of the earth's total land surface and produce $70 \%$ of total $\mathrm{CO}_{2}$ emissions (UN Habitat, 2011). Forest areas absorb approximately $40 \%$ of the $\mathrm{CO}_{2}$ production (Gray, 2011). Thus, increasing the number of trees and plants within a city is crucial. Many cities are introducing smart processes to combat the impact of extreme weather: Carter (2013) citing Songdo in South Korea; Wray (2017) citing Bosco Verticale in Milan, Italy; Liuzhou Forest City in China; examples from Boston, New York, and Chicago in the US; and smart urban forestation projects from Switzerland, Holland, Brazil, Albania, and France. In this context, the benefits of the combined smart and green infrastructure help achieve ecological, socioeconomic, and environmental goals with advantages to citizens.

Cities worldwide face daunting infrastructure challenges due to extreme weather caused by climate change, and extensive research has been conducted on this subject (DfT, 2004; 2014; Chapman, 2014; Leviäkangas et al., 2011). The increased regularity of flooding results in disruptions and expensive repairs, which are estimated at $£ 1$ billion per year (Department for Environment, Food \& Rural Affairs, 2012). A significant proportion of assets are located in areas prone to flooding, and the risk is projected 


\begin{tabular}{|c|c|c|c|c|}
\hline Grey & \multicolumn{2}{|c|}{ Grey/Green } & Smart/Green & Smart \\
\hline $\begin{array}{l}\text { - Transport } \\
\text { infrastructure } \\
\text { networks } \\
\text { - Water \& sewer } \\
\text { pipelines } \\
\text { - Storage basins }\end{array}$ & $\begin{array}{l}\text { - Storage ponds } \\
\text { - Holding tanks } \\
\text { - Controlled } \\
\text { slow release } \\
\text { systems } \\
\text { - Volume peak } \\
\text { rate reduction } \\
\text { systems } \\
\text { - Composite } \\
\text { permeable } \\
\text { drainage } \\
\text { systems }\end{array}$ & $\begin{array}{l}\text { - Network of } \\
\text { multifunctional } \\
\text { green spaces } \\
\text { strategically } \\
\text { planned and } \\
\text { managed } \\
\text { - Networks of } \\
\text { wetlands \& flood } \\
\text { plain restoration }\end{array}$ & $\begin{array}{l}\text { Integrated } \\
\text { management } \\
\text { solutions for } \\
\text { - Storm water } \\
\text { - Flood water } \\
\text { - Coastal } \\
\text { infrastructure } \\
\text { - Urban waste } \\
\text { - Transportation } \\
\text { - Recreation } \\
\text { - Assets }\end{array}$ & $\begin{array}{l}\text { - Technology \& } \\
\text { data networks } \\
\text { for smart pricing } \\
\text { and drainage } \\
\text { systems } \\
\text { - Smart energy grid } \\
\text { systems, transport } \\
\text { \& communication } \\
\text { efficiencies } \\
\text { - Urban } \\
\text { commuting } \\
\text { sensors }\end{array}$ \\
\hline $\begin{array}{l}\text { Built-up \& } \\
\text { assets } \\
\text { centered }\end{array}$ & $\begin{array}{l}\text { Built-up \& } \\
\text { ecology centered }\end{array}$ & $\begin{array}{l}\text { Human \& ecology } \\
\text { centered }\end{array}$ & $\begin{array}{c}\text { Human, ecology \& } \\
\text { technology } \\
\text { centered }\end{array}$ & $\begin{array}{l}\text { Technology \& } \\
\text { communications } \\
\text { centered }\end{array}$ \\
\hline \multicolumn{2}{|c|}{$\begin{array}{l}\text { Traditional technology } \\
\text { focus }\end{array}$} & \multicolumn{2}{|c|}{$\begin{array}{l}\text { Increased environmental } \\
\text { consciousness }\end{array}$} & $\begin{array}{l}\text { Innovative data } \& \\
\text { ommunication systems }\end{array}$ \\
\hline & & \multicolumn{2}{|c|}{$\begin{array}{l}\text { Environmentally friendly, supported by data } \\
\text { and communication systems }\end{array}$} & \\
\hline
\end{tabular}

Fig. 1 Concepts of gray, green, smart, and smart and green infrastructure.

to increase. The projected global warming of $4^{\circ} \mathrm{C}$ by 2080 due to climate change implies a large increase in possible flood damage in the UK. Thus, embedding smart technology systems into the existing infrastructure allows for monitoring, reporting, and even the provision of preventive measures, expanding the capacity and life span of existing assets (Woetzel et al., 2018).

Green infrastructure components, such as natural habitats and wetland features, can reduce coastal and riparian flood risk (UK Green Building Council, 2015). Intense rainfall will cause transport disruptions and increase sewer flooding. The predicted rise in sea levels will increase the proportion of assets vulnerable to coastal flooding (Committee on Climate Change, 2017a). The government assesses the risks every five years to address the major effects of climate change on infrastructure. These assessments (Committee on Climate Change, 2017b) identified that incorporating SGI components in urban development is a significant action in this process. Therefore, breaking away from silo working and combining green infrastructure and smart solutions into integrated SGI systems are urgently needed to address complex city challenges in the future.

\section{Benefits of smart and green infrastructure implementation}

Modern city infrastructure must be strong, resilient, adaptable to climate change, and flexible for improvement considering performance and price. Incorporating green infrastructure can improve resilience, efficiency, and performance, and deliver increased return on investment (Science for Environment Policy, 2012; Kaluarachchi, 2019b). Improving public spaces with green infrastructure within town centers alone can boost commercial trading by up to $40 \%$ (Victoria Business Improvement District, 2013) providing economic benefits. The smart technologies that can be implemented alongside green infrastructure include the following: Public space and utility service management, citizen engagement in decision-making processes, and online activities, including e-commerce (Tobergte and Curtis, 2013; Kaluarachchi, 2019a). Research conducted (NENW, 2008) considering smart and green integrated infrastructure identified the following distinct areas of economic benefits: Economic growth, investment, land and property values, labor productivity, tourism, land products, health and wellbeing, recreation and leisure, quality of place, land and biodiversity, flood alleviation and water management, and climate change adaptation/ mitigation.

The literature review identified numerous benefits for implementing green infrastructure and smart city applications independently and as an integrated concept. The combined benefits illustrate that the integration of smart and green provides the most efficient and effective environmental, social, economic, and health benefits as presented in Fig. 2 (UCLG, 2017; 2019; Woetzel et al., 


\begin{tabular}{|c|c|c|c|}
\hline & $\begin{array}{l}\text { Benefits of Green } \\
\text { Infrastructure }\end{array}$ & $\begin{array}{c}\text { Benefits of Integrated Smart \& } \\
\text { Green Infrastructure }\end{array}$ & $\begin{array}{l}\text { Benefits of Smart } \\
\text { Infrastructure }\end{array}$ \\
\hline \multirow{8}{*}{ 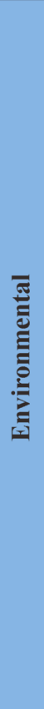 } & $\begin{array}{l}\text { Trees and vegetation } \\
\text { improving air quality }\end{array}$ & $\begin{array}{l}\text { Improved air quality and reduced air } \\
\text { pollution }\end{array}$ & $\begin{array}{l}\text { Sensors for detection of air } \\
\text { pollutants \& air quality }\end{array}$ \\
\hline & $\begin{array}{l}\text { Natural permeable layers } \\
\text { for flood water drainage }\end{array}$ & $\begin{array}{c}\text { Integrated Flood Water Management } \\
\text { Systems - FWMS }\end{array}$ & $\begin{array}{l}\text { Sensors and devices to } \\
\text { monitor water levels }\end{array}$ \\
\hline & $\begin{array}{l}\text { Green roofs, permeable } \\
\text { paving and rain gardens }\end{array}$ & Sustainable Drainage Systems - SUDS & $\begin{array}{l}\text { Sensors and devices to } \\
\text { control water drainage }\end{array}$ \\
\hline & $\begin{array}{c}\text { Green vegetation reducing } \\
\text { urban heat islands }\end{array}$ & $\begin{array}{c}\text { Reducing climate change and extreme } \\
\text { weather impacts }\end{array}$ & $\begin{array}{l}\text { Heat sensors, sensor driven } \\
\text { fans, air conditioning }\end{array}$ \\
\hline & $\begin{array}{l}\text { Reduction in green house } \\
\text { gas emissions }\end{array}$ & Mitigating climate change impacts & $\begin{array}{l}\text { Sensors and devices } \\
\text { improving efficiency }\end{array}$ \\
\hline & $\begin{array}{l}\text { Water conservation by } \\
\text { natural ecosystems }\end{array}$ & $\begin{array}{c}\text { Water Resource Management Systems } \\
- \text { WRMS }\end{array}$ & $\begin{array}{l}\text { Water conservation by } \\
\text { sensors and tracking }\end{array}$ \\
\hline & Reduce, recycle and reuse & Preservation of resources & $\begin{array}{l}\text { Solid waste reduction by } \\
\text { digital tracking }\end{array}$ \\
\hline & $\begin{array}{l}\text { Shading and cooling to } \\
\text { reduce energy consumption }\end{array}$ & Energy efficiency and performance & $\begin{array}{l}\text { Smart metering and better } \\
\text { insulation }\end{array}$ \\
\hline \multirow{6}{*}{$\overline{\bar{s}}$} & $\begin{array}{l}\text { Recreational outdoor spaces } \\
\text { to improve quality of life }\end{array}$ & $\begin{array}{l}\text { Secure recreational outdoor spaces for } \\
\text { physical \& mental health and wellbeing }\end{array}$ & $\begin{array}{l}\text { Security and safety by } \\
\text { monitoring and surveillance }\end{array}$ \\
\hline & $\begin{array}{c}\text { Facilities, spaces for } \\
\text { socially inclusive activities }\end{array}$ & $\begin{array}{l}\text { Socially connected inclusive } \\
\text { communities }\end{array}$ & $\begin{array}{l}\text { Social media connectedness } \\
\text { to improve interactions }\end{array}$ \\
\hline & $\begin{array}{l}\text { Residents engaged in local } \\
\text { development decisions }\end{array}$ & $\begin{array}{l}\text { Community engaged governance } \\
\text { processes and decision making }\end{array}$ & $\begin{array}{c}\text { Engaging via smart } \\
\text { applications and technology }\end{array}$ \\
\hline & $\begin{array}{l}\text { Improved usage of public } \\
\text { spaces and surveillance }\end{array}$ & $\begin{array}{c}\text { Reduction in crime \& improved } \\
\text { policing }\end{array}$ & $\begin{array}{l}\text { Real time crime mapping, } \\
\text { fast emergency responses }\end{array}$ \\
\hline & $\begin{array}{l}\text { Pedestrianisation and green } \\
\text { ways to improve safety }\end{array}$ & Improved mobility and traffic safety & $\begin{array}{l}\text { Traffic management via } \\
\text { remote monitoring }\end{array}$ \\
\hline & $\begin{array}{l}\text { Sustainable public transport } \\
\text { including green ways }\end{array}$ & $\begin{array}{c}\text { Reduced } \mathrm{CO}_{2} \text { emmissions, pollutions } \\
\text { and improved air quality }\end{array}$ & $\begin{array}{c}\text { Improved commuter time } \& \\
\text { traffic mitigation }\end{array}$ \\
\hline \multirow{4}{*}{ 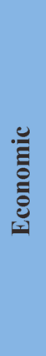 } & $\begin{array}{l}\text { Local service providers } \\
\text { aware of local requirements }\end{array}$ & $\begin{array}{c}\text { Local markets with access to global } \\
\text { markets and services }\end{array}$ & $\begin{array}{l}\text { Access to global services } \\
\text { and markets }\end{array}$ \\
\hline & $\begin{array}{l}\text { Local businesses, identity, } \\
\text { and local markets }\end{array}$ & $\begin{array}{l}\text { Sustainable local work places and } \\
\text { community identity }\end{array}$ & $\begin{array}{l}\text { Access to international } \\
\text { labour markets travel }\end{array}$ \\
\hline & $\begin{array}{l}\text { Local networks supported } \\
\text { by global protocols }\end{array}$ & $\begin{array}{c}\text { More control in privacy and data } \\
\text { protection issues }\end{array}$ & $\begin{array}{c}\text { Privacy and data protection } \\
\text { challenges }\end{array}$ \\
\hline & $\begin{array}{l}\text { Innovation in finding nature } \\
\text { based solutions }\end{array}$ & Innovative ecofriendly solutions & $\begin{array}{l}\text { Platform for innovative } \\
\text { technologies }\end{array}$ \\
\hline \multirow{3}{*}{ 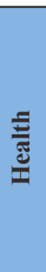 } & $\begin{array}{c}\text { Balanced ecosystems } \\
\text { contribute to health and } \\
\text { wellbeing }\end{array}$ & \multirow{3}{*}{$\begin{array}{c}\text { Improved health systems and } \\
\text { quality of life }\end{array}$} & $\begin{array}{l}\text { Applications to prevent, } \\
\text { treat, and monitor health } \\
\text { conditions and diseases }\end{array}$ \\
\hline & $\begin{array}{l}\text { Locally engaged health } \\
\text { services }\end{array}$ & & $\begin{array}{c}\text { New ways of engagement } \\
\text { with patients }\end{array}$ \\
\hline & $\begin{array}{l}\text { Participatory decision } \\
\text { making }\end{array}$ & & $\begin{array}{c}\text { Use of data to fight diseases } \\
\text { and prevent spreading }\end{array}$ \\
\hline
\end{tabular}

Fig. 2 Benefits of implementing green and smart infrastructure independently and as integrated. 
2018; NGICP and IGICP, 2018; Smart Cities World, 2018; Kaluarachchi, 2019b).

\section{Applications of integrated smart and green infrastructure systems}

Cities face a wide range of environmental challenges that pose significant risks to their economic and social futures. These challenges include climate hazards, such as storms, flooding, cyclones, coastal erosion, rising energy and carbon footprints, and risks to water security and natural habitats. Many infrastructure systems are co-dependent on each other, and failure of one system can have repercussions on others. The UK infrastructure is more prone to flooding than any other climate risk (Committee on Climate Change, 2017a). Storms and floods, paired with the failure of coastal infrastructure, have a direct impact on transportation systems that are key to many urban city services. Similarly, transport infrastructure assets, such as bridges, roads, ports, harbors, underground structures, and tunnels, are directly impacted by storms and flooding.

\subsection{Stormwater management}

Green infrastructure components, such as vegetation and layers of soil systems, can soak up rainwater by mimicking natural filtration and are crucial in sustainable water drainage. The rate of runoffs for natural green areas is estimated to be $10 \%-20 \%$, while that for artificial surfaces is $65 \%$ (Natural England, 2015). Urban community garden plots, which provide many benefits, including food production, recreation activities, and recycling of waste and rainwater, can be made efficient by incorporating realtime sensors that monitor water levels (Carter, 2013). Combining and embedding these green solutions with smart "Continuous Monitoring and Adaptive Control" systems provides a practical solution to enhance the performance and value of existing stormwater management infrastructure. This technology integrates information from field-deployed environmental and water-level instrumentation with real-time weather forecast data to monitor the performance directly and actively control stormwater storage and flows (Wright and Marchese, 2017).

\subsection{Flood water management}

The number of assets exposed to flooding could double under expected changes in climate by the 2080s (Committee on Climate Change, 2017a). Rain runoffs weaken dams, railroad beds, bridges, and buildings (Titus, 2002). The non-porosity of many hard, built surfaces raises the probability of flash floods. Green infrastructure components incorporated with smart technologies, such as sensors and valves, as well as soft opening and closing vent systems, can be utilized in flood management systems. Building information modeling (BIM) has been applied in flood prevention in Ipswich, UK to manage the design of a new tidal barrier across the River Orwell. The 3D models have assisted in decision making, construction planning, and assessing spatial coordination of the staff for health and safety briefings (Beadenkopf, 2019). In these solutions, combinations of nature-based green infrastructure components and smart technology are utilized to reach optimum solutions that can mitigate extreme weather impacts.

\subsection{Coastal infrastructure management}

Coastal changes through erosion, storm surges, or permanent inundation have remained a risk to coastal infrastructure. Sea level rise due to climate change is a critical factor influencing coastal erosion rates (Environment Agency, 2016). Traditionally, gray infrastructure assets were used as coastal defenses, adopting an engineering approach by raising floodwalls and strengthening embankments to protect against storms. Integrated green solutions include natural wetland and shrubs in between the coastline and land, which act as buffers that can adapt to the changes through time, rather than creating hard, man-made defenses. Combining these nature-based solutions with novel mapping systems, such as Geographic Information System (GIS), and simulation techniques, such as BIM, provides a considerable understanding of the response to coastal erosion. Survey techniques, such as smart robots and drones, provide data for simulating the coastal areas and seabed in storm surges to model their behavior and plan for future extreme weather events.

\subsection{Urban waste management}

Recycling and reusing waste, a sector that can utilize smart waste management techniques, is a critical challenge in modern cities. Water can be filtered and used as green or blue infrastructure features or to service these features combining smart and green. Southern California in the USA has successfully converted wastewater to drinking water (Carter, 2013). The Internet of Things (IoT) has assisted in realizing "Smart Urban Waste Management" techniques, allowing the efficient waste collection and performance optimisation. The IoT is known as the amalgamation of entrenched system hardware and wireless communication networks that convey sensor data to computing devices for analysis in real-time (Bande and Shete, 2017). Route selection is enhanced in accordance with bin fill levels by using these smart processes (Anwar, 2018). The combination of these smart systems with green recycling and re-use techniques has resulted in effective and sustainable urban city solutions. 


\subsection{Transportation management}

Transport is one of the largest contributors to greenhouse gases emissions. In the UK, road transport increased by $6 \%$ between 1990 and 2017 (Office for National Statistics, 2018). The fast expansion of smart mobility services has a considerable potential to reduce motorized traffic. Improving the daily commuting time and conditions is critical to the quality of life of the modern urban workforce. Cities with long-term sustainable green city goals promote public transport, walking, cycling, and car-sharing with low pollution and traffic congestion (Kaluarachchi, 2019b). The potential to reduce traffic volumes and commuter time with smart applications varies according to the existing infrastructure, density, capacity, and traffic volumes of each city. E-commerce has changed the way people move due to an increase in the number of people sharing rides, integrated schedules and ticketing methods, electric vehicles, and smart parking systems. Combined green and smart transportations include the following: Uber (data-driven transit services), Zipcars (ICT-enabled shared cars in the US), and community bike-sharing. These smart transport methods have provided citizens many options to be mobile without owning a private vehicle (Fang, 2015).

\subsection{Recreation and outdoor spaces management}

Smart recreational facilities, parks, and wetlands are important in improving the quality of life of citizens. Increasing the recreational and physical activities of a city's population is linked to improvements in health and wellbeing and results in reductions in health care costs due to a healthy population (Foster et al., 2016). Gardens and green roofs utilized for stormwater drainage can also be used for urban recreational spaces due to their aesthetic value. Smart security lighting systems can make these spaces appealing for public use. Examples of smart and green components include smart water feature controls, smart and intelligent security lighting systems, interactive areas for children, elderly, and the disabled, energygenerating exercise equipment, and automated garden maintenance techniques (Jessup, 2018).

\subsection{Asset management}

Smart technologies can provide improvements in efficiency and greater capacity by delivering detailed, realtime information on the use of assets, enabling infrastructure providers to plan and manage capacity effectively. Infrastructure assets comprise over- and underground built assets, including transport-related assets, such as tunnels and ancillary buildings, which incur a large proportion of construction, maintenance, and rehabilitation costs. The risk of storm surge, flooding, and sea-level rise increases the vulnerability of transportation infrastructure, including bridges, roads, tunnels, ports, and harbors (Martinez et al., 2018). Hence, the collaboration between stakeholders with the support of digital smart technology is essential to the efficient running of these integrated and codependent systems.

Sensors embedded within built assets can provide realtime feedback for monitoring. Proactive mechanisms enable new maintenance, inspection, and refurbishment regimes focusing on preventive maintenance (Mair, 2015). The UK is championing "Green Asset Management" concepts, promoting climate-related financial disclosures to help fund managers identify green and low-carbon opportunities to boost investment into innovative clean technologies through state investment and grant funding. London, UK is known to be the leading center in green advisory services, green project financing, and funding climate adaptation, offering a complete portfolio of opportunities to green asset managers (Department for International Trade, 2018).

\section{Integrated smart and green nature-based solutions for future cities}

Smart cities are enabling the next wave of public investment worldwide (Woetzel et al., 2018) and are predicted to deliver more than $\$ 20$ trillion in additional economic benefit by 2026 (Smart Cities World, 2018). Concerns have been raised that smart cities, especially new purpose-built smart cities, have isolated people rather than build inclusive communities. Many cities prioritise technology and are known to be devoid of factors that contribute to the quality of life of the residential community, as illustrated by the following examples.

- Masdar City, Abu Dhabi - The world's first zeroemission, eco-friendly city is known to be a ghost town without people (Liu, 2018). Studies conducted indicate that this city will not reach the sustainability goals upon completion (Goldenberg, 2016).

- Songdo, South Korea - This city, promoted as the perfect example of a smart sustainable city with networked computers controlling all aspects of life, is having difficulty attracting businesses and residents. Only a third of the residential developments are occupied and businesses are few (Albert, 2019). Songdo is developing a reputation as a "lonely and transparent city" where neighbors do not meet or communicate, and most communications are known to take place online (Poon, 2018).

- Eko-Atlantic, Nigeria - A waterfront reclamation project with a vision to become Africa's financial smart city center (Albert, 2019). Critics argued that the project is exclusively for the wealthy, thus lacking transparency. The most significant flaw of this project, the breakwater, which is proposed to withstand winds and waves from the 
Atlantic Ocean, has since pushed waves into neighboring parts of Lagos, resulting in devastating floods (Onuoha, 2017).

Numerous examples have raised the need for peoplecentered urban city concepts where nature-based solutions are combined with smart infrastructure to provide benefits of health and well-being while addressing the social, economic, and environmental challenges of urban cities. One example is Sidewalk Toronto, a project by Alphabet (Google) that has taken on the lessons from previous smart cities and planned to install various technologies to enhance efficiency and quality of life in a new waterfront neighborhood. Data and privacy concerns have been raised regarding the development (Albert, 2019), and the lessons from this project will benefit many other cities in the future.

Modern-day demands in careers, mixing groups of different socio-economic classes, or the marginalisation of racial or ethnic groups contribute to the susceptibility of citizens to mental health problems (Moudon, 2009; Hammersen et al., 2016). Breakdown of relationships and families can also reduce social cohesion. The transient nature of commuters and temporary residents in the city contributes to this reduction in social cohesions and increases poor mental health. Additionally, cities have many environmental stresses including ambient noise, considerable visual stimulation, and light pollution (Chepesiuk, 2009). Grey or smart infrastructure alone cannot respond to these psychological conditions. Thus, green infrastructure and nature-based urban systems can assist in reducing the negative environmental impact. Hence, a new wave of thinking involves the promotion of the integration of green and smart solutions that encourage well-being, security, and social and community cohesion rather than focusing on efficient smart systems that only promote economic efficiency. In future cities, smart solutions can be used to enhance social cohesion and create a new type of digital social connectedness through digital APPs and platforms. These solutions result in a governance system that engages communities in the decision-making processes of local government. New channels for public communication with local officials could help in the responsiveness of city governments to their populations. Many city agencies already maintain an active presence on social networks, and others have developed their interactive citizen APPs to improve participatory decision-making.

Exploring and amplifying the power of nature-based solutions is a key priority for the World Bank (2019) as illustrated by the Nature-Based Initiative, which encourages countries to "scale-up nature-based solutions to harness the power of nature to reduce disaster risk and strengthen climate resilience in development projects". The innovations in technology provide an opportunity to combine these solutions with smart systems that can deal with a complex city. GIS is such a system that can integrate data from various sources, which collects, stores, models, analyses, and uses data for alphanumerical and graphical presentations (Crncevic et al., 2017).

The smooth functioning and long-term sustainability of infrastructure systems and related assets are key to the efficient operation and performance of future cities. While the reliance on data-driven smart technology increases, focusing on data sharing and the development of virtual platforms can maximise the efficient use of resources to provide benefits to multiple integrated systems. Combining sustainable drainage systems that consider storms, floods, and coastal water management systems with transport and asset management will provide resource efficacy to numerous sectors. Rapid urbanisation and population increase have created high demand for urban land and increased traffic congestion. Thus, substantial investment in mobility, especially in transportation infrastructure, is needed. Roads and underground tunnels are important components in these systems and using green and smart technology coupled with data-driven digital monitoring and reporting can provide numerous benefits. Safety and efficiency can be severely affected by extreme weather events, while real-time data can identify criteria for system failures in advance. Hence, urban resilience against climate change can be realized.

Big Data, a term that describes the large volume of data (structured and unstructured) (SAS, 2018), has a vital role in the design and operation of smart and green cities. Organisations can analyze Big Data for insights that lead to informed decisions and strategic business moves. Smart grids, urban wind power, geothermal energy, and smart lights are smart technologies that also help cities become green and connected and increase awareness of the importance of sustainable infrastructure for growth (Mell, 2013). New sensor technologies produce large amounts of data to provide a new understanding of a nation's city infrastructure. The need to manage these data in an integrated way drives the development of new smart green city standards that address social, economic, and environmental requirements. Security, privacy, and data protection are important in city governance to gain the confidence of citizens. Several cities have already implemented transparent smart city governance systems to engage citizens and promote participatory decision making (UCLG, 2017; 2019)

The future-proofing of cities to attain long-term sustainability and combat climate change challenges will require responsive and adaptive infrastructure. This requirement ensures that the systems, including networks, sensors, and communication channels, are robustly monitored, and data are collected and reported effectively to make informed decisions. The analysis suggests a shift from silo infrastructure usage to integrated smart and green infrastructure systems that provide environmental, health, and socio-economic benefits. These integrated systems can respond to stakeholder needs. However, additional 
insights, research, and development are needed in many areas (for example, cost-benefit analysis of climate change adaptation, city performance indicators, urban systems, smart network modeling, and community participation and engagement via digital technology) to advance toward achieving future cities. Stakeholders must be informed of the capabilities of the combined smart-green solutions rather than their silo counterparts to mainstream these integrated and co-dependent systems. Supported by datadriven developments, such as Big Data and IoT, integrated infrastructure systems will have the capabilities to achieve future cities, thereby promoting smart governance, smart living and communities, smart mobility, and smart economy and environments (Fig. 3).

\section{Conclusions}

Many examples show that integrated smart and green solutions provide better socio-ecological results than gray, green, or smart silos. Governments must find the right combination of technologies, investments, policies, and partners suitable for the priorities of their residents. Decision-makers must also consider the maintenance and enhancement of a city's character as it becomes digitised and automated. The interfaces must be engaging and intuitive, emphasizing good design in the user experience. Smart technologies have the potential to innovate and are best utilized alongside nature-based solutions that promote the health and wellbeing of residents. Despite the potential of these technologies to distance residents from one another, cities can benefit from its use in essential services. Cities can promote personal connections via social networks to mitigate this social distancing. Social networks can facilitate volunteering, mentoring, parenting support, and community activities on a broad scale.

Achieving smart and green cities within contemporary urban design and planning practice is challenging due to the two agendas are employed independently. Thus, a coordinated approach and identification of dependencies and commonalities are needed to achieve long-term sustainability. Innovative sensor and communication technologies are vital components to the future of city infrastructure and will play a role in the future relationship of society considering privacy, mobility, and communication. The traditional gray infrastructure solved only one particular problem of a large system - water, waste, or transportation. This model has now shifted to incorporate multifunctional infrastructure systems that are dependent on each other. This shift is crucial, and the integration provides the potential to serve multiple interests of different sectors. Many modern cities have traditional,

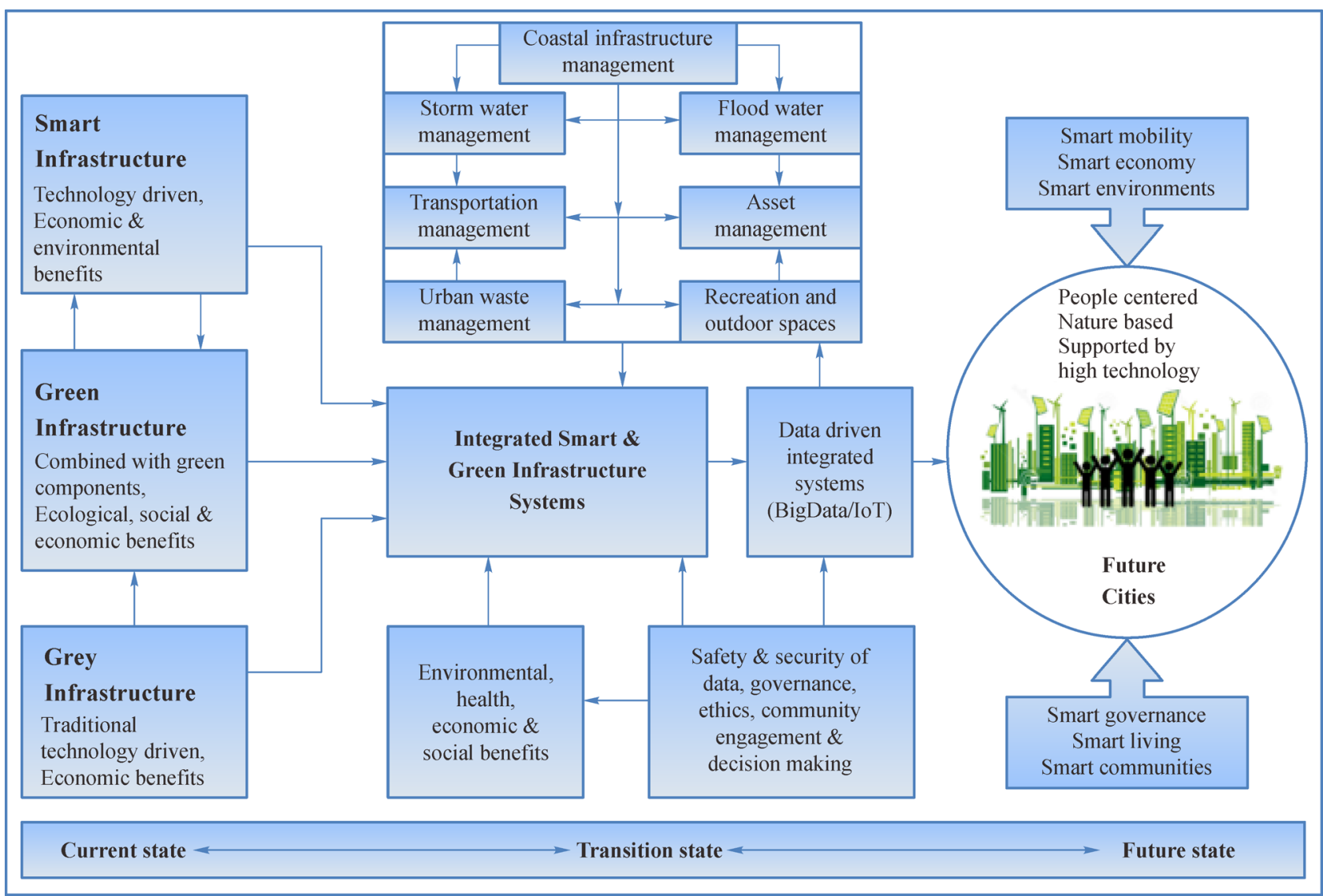

Fig. 3 Integrated infrastructure systems and drivers that contribute to achieving future cities. 
outdated gray infrastructure. Thus, refurbishing these elements and systems will provide an opportunity to incorporate smart green components.

A viable smart green infrastructure strategy will require new legislation for new types of urban development. Thus, all stakeholders must work together with a changed mindset and a common goal for the successful implementation of this strategy. An integrated approach will be beneficial for all sectors and will need effective collaborations. Future cities must be people-centered and use technology appropriately to unite and connect the city services and the residents. Technology is a tool in the optimisation of infrastructure, resources, and shared spaces. Future cities must be on the cutting edge of innovation. However, avoiding excessive involvement in a technological vision and maintaining focus on real people is critical. The physical and mental health and wellbeing of the residents are of critical importance to the quality of life in the city. Therefore, combined smart, green, and naturebased infrastructure must rise to the challenges.

Open Access This article is licensed under a Creative Commons Attribution 4.0 International License, which permits use, sharing, adaptation, distribution and reproduction in any medium or format, as long as you give appropriate credit to the original author(s) and the source, provide a link to the Creative Commons licence, and indicate if changes were made.

The images or other third party material in this article are included in the article's Creative Commons licence, unless indicated otherwise in a credit line to the material. If material is not included in the article's Creative Commons licence and your intended use is not permitted by statutory regulation or exceeds the permitted use, you will need to obtain permission directly from the copyright holder. To view a copy of this licence, visit http:// creativecommons.org/licenses/by/4.0/.

\section{References}

Albert S (2019). Smart cities: The promises and failures of utopian technological planning. Available at: phys.org/news

Alberta Water Portal Society (2019). Introduction to green infrastructure and grey infrastructure. Available at: albertawater.com/green-vsgrey-infrastructure

Albino V, Berardi U, Dangelico R M (2015). Smart cities: Definitions, dimensions, performance, and initiatives. Journal of Urban Technology, 22(1): 3-21

Anwar S H (2018). Use cases of Internet of Things: Smart urban waste management. Available at: medium.com/blueeast

Bande S, Shete V V (2017). Smart flood disaster prediction system using IoT \& neural networks. In: International Conference on Smart Technologies for Smart Nation (SmartTechCon). Bangalore: IEEE, 189-194

Beadenkopf E (2019). Taking BIM to the infrastructure level. Available at: snclavalin.com/en/beyond-engineering

Benedict M A, McMahon E T (2002). Green infrastructure: Smart conservation for the 21 st century. Renewable Resources Journal, 20 (3): $12-17$

Browder G, Ozment S, Bescos I R, Gartner T, Lange G M (2019). Integrating green and gray: Creating next generation infrastructure.
Washington, DC: World Bank and World Resources Institute

Brown R D, Vanos J K, Kenny N A, Lenzholzer S (2015). Designing urban parks that ameliorate the effects of climate change. Landscape and Urban Planning, 138: 118-131

Carter T (2013). Smart cities: The future of urban infrastructure. BBC Future. Available at: flipboard.com/topic/sustainablearchitecture

Chapman L (2014). A climate change report card for infrastructure. Research \& Innovation for our Dynamic Environment (RIDE) Forum Working Technical Paper

Chepesiuk R (2009). Missing the dark: Health effects of light pollution. Environmental Health Perspectives, 117(1): A20-A27

Committee on Climate Change (2017a). UK Climate Change Risk Assessment. Synthesis report: Priorities for the next five years. Available at: theccc.org.uk/uk-climate-change-risk-assessment-2017/ synthesis-report/

Committee on Climate Change (2017b). UK Climate Change Risk Assessment. Evidence report. Available at: theccc.org.uk/uk-climatechange-risk-assessment-2017/

Crncevic T, Tubic L, Bakic O (2017). Green infrastructure planning for climate smart and "green" cities. Spatium, 3(38): 35-41

Department for Environment, Food \& Rural Affairs (2012). UK climate change risk assessment: Government report. Available at: gov.uk/ government/publications

Department for International Trade (2018). The UK - a natural home for green asset management, wealth and investment management. Available at: informaconnect.com/

DfT (2004). The changing climate: Impact on the Department for Transport. London: Department for Transport (DfT)

DfT (2014). Transport resilience review-a review of the resilience of the transport network to extreme weather events. London: Department for Transport (DfT)

Environment Agency (2016). Managing flood and coastal erosion risks in England: 1 April 2014 to 31 March 2015. Corporate Report

Fang K (2015). "Smart Mobility": Is it the time to re-think urban mobility? The World Bank Group. Available at: blogs.worldbank. org/transport

Foster J, Lowe A, Winkelman S (2011). The value of green infrastructure for urban climate adaptation. Washington, DC: Center for Clean Air Policy

Foster L, Heller B, Williams A, Dunn M, Curtis D, Goodwill S (2016). Development of smart inner-city recreational facilities to encourage active living. In: Ubiquitous Computing and Ambient Intelligence. Springer, 458-468

Godfrey N, Savage R (2012). Future proofing cities: Risks and opportunities for inclusive urban growth in developing countries. Epsom: Atkins

Goldenberg S (2016). Masdar's zero-carbon dream could become world's first green ghost town. Available at: theguardian.com/ environment/2016/feb/16/

Gray L (2011). World's forests absorb almost 40 percent of man-made $\mathrm{CO}_{2}$. Available at: telegraph.co.uk/news/earth/earthnews/8708979/

Habitat UN (2011). Hot cities: Battle-ground for climate change. Global Report on Human Settlement

Hammersen F, Niemann H, Hoebel J (2016). Environmental noise annoyance and mental health in adults: Findings from the crosssectional German health update (GEDA) study 2012. International 
Journal of Environmental Research and Public Health, 13(10): 954

International Telecommunication Union (ITU) (2014). Smart sustainable cities: An analysis of definitions. Technical Report. ITU Telecommunication Standardization Sector (ITU-T) Focus Group on Smart Sustainable Cities (FG-SSC)

Jessup K (2018). The smart cities toolkit for SMART Urban Parks. Available at: meetingoftheminds.org

Kaluarachchi Y (2019a). Smart and green infrastructure for future cities. In: International Conference on Innovation, Technology, Enterprise and Entrepreneurship

Kaluarachchi Y (2019b). Improving urban city resilience by incorporating smart green infrastructure components. In: CIB World Building Congress. Hong Kong

Lennon M (2015). Green infrastructure and planning policy: A critical assessment. Local Environment, 20(8): 957-980

Leviäkangas P, Tuominen A, Molarius R, Kojo H, Schabel J, Toivonen S, Keränen J, Ludvigsen J, Vajda A, Tuomenvirta H, Juga I, Nurmi P, Rauhala J, Rehm F, Gerz T, Mühlhausen T, Schweighofer J, Michaelides S, Papadakis M, Dotzek N (2011). Extreme weather impacts on transport systems. EWENT Project Deliverable D1. VTT Working Papers 168

Liquete C, Kleeschulte S, Dige G, Maes J, Grizzetti B, Olah B, Zulian G (2015). Mapping green infrastructure based on ecosystem services and ecological networks: A Pan-European case study. Environmental Science \& Policy, 54: 268-280

Liu C (2018). Oil-rich Abu Dhabi's Masdar City: Green oasis or green ghost town? Available at: scmp.com/week-asia/business/article/ 2133409

Mair R (2015). How will city infrastructure and sensors be made smart? Cambridge Centre for Smart Infrastructure and Construction

Martinez E, Hernandez J, Rodriguez-Nikl T, Mazari M (2018). Resilience of underground transportation infrastructure in coastal regions: A case study. In: International Conference on Transportation and Development: Planning, Sustainability, and Infrastructure Systems. Pittsburgh, 223-230

Mell I C (2013). Can you tell a green field from a cold steel rail? Examining the "green" of green infrastructure development. Local Environment, 18(2): 152-166

Moudon A V (2009). Real noise from the urban environment: How ambient community noise affects health and what can be done about it. American Journal of Preventive Medicine, 37(2): 167-171

Natural Economy Northwest (NENW) (2008). The economic value of green infrastructure. Available at: inherit.eu/

NGICP and IGICP (2018). National green infrastructure certification program glossary. Available at: ngicp.org/

Natural England (2015). Natural England's green infrastructure guidance. Available at: publications.naturalengland.org.uk/publication $/ 35033$

Office for National Statistics (2018). UK environmental accounts, atmospheric emissions datasets. Available at: ons.gov.uk/economy/ environmentalaccounts/datasets/

Onuoha M (2017). A 5-mile island built to save Lagos's economy has a worrying design flaw. Available at: qz.com/africa/923142/

Papayanis N, Wakeman R (2019). The urban infrastructure. Available at: encyclopedia.com/international/encyclopedias-almanacs-transcripts- and-maps/urban-infrastructure

Poon L (2018). Sleepy in Songdo, Korea's smartest city. Available at: bloomberg.com/news/articles/2018-06-22/

Quant (2019). Smart networks. Available at: quant.network/insights

SAS (2018). Big Data-What it is and why it matters. Available at: sas. com/en_us/insights/big-data/what-is-big-data.html

Science for Environment Policy (2012). The multifunctionality of green infrastructure. European Commission

Smart Cities World (2018). Smart cities report forecasts trillions in economic growth. Available at: smartcitiesworld.net/news/

Talberth J, Gray E, Yonavjak L, Gartner T (2013). Green versus gray: Nature's solutions to infrastructure demands. Solutions, 4(1): 40-47

Talberth J, Hanson C (2012). Green vs. gray infrastructure: When nature is better than concrete. World Resources Institute

The World Bank (2019). Putting nature to work: Integrating green and gray infrastructure for water security and climate resilience. Available at: worldbank.org/en/news/feature/2019/03/21/green-andgray

Titus J (2002). Does sea level rise matter to transportation along the Atlantic coast? In: The Potential Impacts of Climate Change on Transportation. Federal Research Partnership Workshop, Summary and Discussion Papers. Washington, DC: Department of Transportation Center for Climate Change and Environmental Forecasting

Tobergte D, Curtis S (2013). Mapping smart cities in the EU. Journal of Chemical Information and Modeling, 53(9): 1689-1699

UK Green Building Council (2015). Green building council demystifying green infrastructure. London

United Cities and Local Governments (UCLG) (2017). Smart cities study 2017. Bilbao: The Committee of Digital and Knowledge-Based Cities of UCLG

United Cities and Local Governments (UCLG) (2019). Smart cities study 2019. Bilbao: The Committee of Digital and Knowledge-Based Cities of UCLG

United Nations (UN) (2018). 68\% of the world population projected to live in urban areas by 2050, says UN. New York: Department of Economic and Social Affairs

Urban Resilience (2019). What is urban resilience? Rockefeller Foundation. Available at: medium.com/100-resilient-cities/

Victoria Business Improvement District (2013). Green Infrastructure audit— best practice guide. Available at: london.gov.uk/WHAT-WEDO/environment/environment-publications/

Wang J, Banzhaf E (2018). Towards a better understanding of Green Infrastructure: A critical review. Ecological Indicators, 85: 758-772

Wentworth J (2013). Urban green infrastructure. POSTnote POST-PN448. Parliamentary Office of Science and Technology of the UK Parliament (POST)

Woetzel J, Remes J, Boland B, Lv K, Sinha S, Strube G, Means J, Law J, Cadena A, von der Tann V (2018). Smart cities: Digital solutions for a more livable future. McKinsey Global Institute

Wray S (2017). Why smart city infrastructure is going green? Special Reports. Smart Cities World

Wright J, Marchese D (2017). Briefing: Continuous monitoring and adaptive control: The "smart" storm water management solution. In: Proceedings of the Institution of Civil Engineers-Smart Infrastructure and Construction, 170(4): 86-89 